\title{
Acute appendicitis and the importance of clinical diagnosis
}

\author{
Antonio Juan-Pastor \\ Institut Català de la Salut, Barcelona, Spain
}

Dear editor:

I have read with interest the article "Acute appendicitis clinical presentation in patients immunocompromised by diabetes or HIV/AIDS"1 and I would like to make some complementary comments on the importance of clinical suspicion in acute appendicitis and some particularities in special situations. First, the systematic use of predictive risk scales, such as the one by Alvarado ${ }^{2}$ or the most recently proposed by the INFURG-SEMES group, tested in 331 patients of between two and 20 years of age, ${ }^{3}$ should be mandatory in the clinical assessment of patients with suspected acute appendicitis. The scale proposed by the INFURG-SEMES group includes male gender, pain in the right iliac fossa on examination, pain to percussion, pain when ambulating, neutrophilia and C-reactive protein, which, like the Alvarado scale, enables classifying patients into three risk groups. The results showed a superior predictive value to that of the Alvarado scale.
On the other hand, another recent study assessed acute appendicitis in pregnancy, ${ }^{4}$ a circumstance that modifies clinical manifestations; Alvarado scale mean score was found to be lower in pregnant women, who present less often with pain in the left iliac fossa and pain upon decompression, which translates into delay in diagnosis and greater complications.

\section{References}

1. Ponce de León-Ballesteros G, Pérez-Soto R, Zúñiga-Posselt $K$, Velázquez-Fernández D. Presentación clínica de la apendicitis aguda en pacientes inmunocomprometidos por diabetes o VIH/sida. Gac Med Mex. 2018;154:473-479.

2. Alvarado A. A practical score for the early diagnosis of acute appendicitis. Ann Emerg Med. 1986;15:557-64.

3. Altali K, Ruiz-Artacho P, Trenchs V, Martínez Ortiz de Zárate M, Navarro C, Fernández C, et al. Escala INFURG-SEMES para el diagnóstico de apendicitis aguda en los pacientes de 2 a 20 años atendidos en los servicios de urgencias hospitalarios. Emergencias. 2017;29: 231-236.

4. Tinoco-González J, Rubio-Manzanares M, Senent-Boza A, Durán-Muñoz V, Tallón-Aguilar L, Pareja-Ciuró $\mathrm{F}$, et al. Diferencias en la presentación clínica, manejo y resultados de la apendicitis aguda en el embarazo. Emergencias. 2018;30:261-264.
Gac Med Mex. 2019;155:106-106

Contents available at PubMed www.gacetamedicademexico.com 